\title{
Pengaruh Penerapan Standar Akuntansi Pemerintah dan Kualitas Aparatur terhadap Laporan Keuangan pada kantor Camat Pamatang Silima Kuta Kab. Simalungun
}

\author{
Mohd. Idris Dalimunthe \\ Program Studi Akuntansi, Fakultas Ekonomi dan Bisnis, Universitas Medan Area \\ Jl. Setia Budi No. 79 B, Kec. Medan Sunggal, Kota Medan, Sumatera Utara \\ E-mail: idris_dalimunthe@yahoo.co.id
}

Received: Februari 2021; Accepted: Mei 2021; Published: Juni 2021

\begin{abstract}
This study aims to determine partially and simultaneously the effect of the adoption of government accounting standards (X1) and the quality of the local government apparatus (X2) on local government financial reports (Y). The type of research used is associative. The population in this study were all employees in the Pamatang Silima sub-district office, Simalungun Regency, as many as 70 people. The sample of this study is employees who meet the criteria of 32 employees. Types of data used in this study are primary data. The data source used in this study is primary data. The technique used by the author to collect the data needed in research is a questionnaire. This study uses multiple linear analysis techniques using SPSS Version 21. The results show that partially government accounting standards (X1) have a significant effect on local government financial reports, the quality of local government apparatus (X2) influences and not significantly on local government financial reports . And simultaneously government accounting standards and the quality of local government officials affect the financial statements of local governments.
\end{abstract}

Keywords: government accounting standards; the quality of local government officials; local government financial reports.

\begin{abstract}
Abstrak
Penelitian ini bertujuan untuk mengetahui secara parsial dan simultan Pengaruh penerapan standar akuntansi pemerintah (X1) dan kualitas aparatur pemerintah daerah (X2) Terhadap laporan keuangan pemerintah daerah $(\mathrm{Y})$. Jenis penelitian yang digunakan adalah asosiatif. Populasi pada penelitian ini adalah Seluruh karyawan yang ada di kantor camat pamatang silima kuta KAB. Simalungun yaitu sebanyak 70 orang. Sampel penelitian ini adalah karyawan yang memenuhi kriteria yaitu 32 karyawan. Jenis data yang digunakan dalam penelitian ini adalah data primer.Sumber data yang digunakan dalam penelitian ini adalah data primer. Teknik yang dilakukan penulis untuk mengumpulkan data yang dibutuhkan dalam penelitian adalah kuesioner.Penelitian ini menggunakan teknik analisis linear berganda dengan menggunakan bantuan SPSS Versi 21. Hasil penelitian menunjukkan bahwa secara parsial standar akuntansi pemerintah (X1) berpengaruh signifikan terhadap laporan keuangan pemerintah daerah, kualitas aparatur pemerintah daerah (X2) berpengaruh dan tidak signifikan terhadap laporan keuangan pemerintah daerah. Dan secara simultan standar akuntansi pemerintah dan kualitas aparatur pemerintah daerah berpengaruh terhadap laporan keuangan pemerintah daerah.
\end{abstract}

Kata kunci: standar akuntansi pemerintah; kualitas aparatur pemerintah daerah; laporan keuangan pemerintah daerah.

\section{PENDAHULUAN}

Standar Akuntansi Pemerintahan mengatur penyajian laporan keuangan untuk tujuan umum dalam rangka meningkatkan perbandingan laporan keuangan baik terhadap anggaran, antar periode, maupun antar entitas. Laporan Keuangan untuk tujuan umum adalah laporan keuangan yang ditujukan untuk memenuhi kebutuhan bersama sebagian besar pengguna laporan.Untuk mencapai hal tersebut, Standar Akuntansi Pemerintahan menetapkan seluruh

doi: https://doi.org/10.51544/jma.v6i1.1788

(C) 2021 Jurnal Mutiara Akuntansi. This is an open access article under the CC BY-SA license

Website: http://e-journal.sari-mutiara.ac.id/index.php/JMA/

http://e-journal.sari-mutiara.ac.id 
pertimbangan dalam rangka penyajian laporan keuangan, pedoman struktur laporan keuangan dan persyaratan minimum isi laporan keuangan (Zeyn, 2011).

Kualitas aparatur pemerintah daerah dalam suatu organisasi terutama organisasi pemerintahan terkait upaya mencapai tujuan yang telah ditetapkan, tidak bisa terlepas dari adanya unsur sumber daya manusia sebagai penggerak jalannya organisasi.Sumber daya manusia menjadi penentu berjalan tidaknya suatu, selain ketersediaan sarana mau pun prasarananya.Organisasi membutuhkan sumber daya manusia yang berkualitas untuk dapat mencapai tujuan yang sudah ditentukan.Agar terdapat manusia-manusia yang berkualitas atau manusia yang berdaya guna dan berhasil guna perlu adanya manajemen sumber daya manusia (MSDM).

Fenomena yang terjadi adalah laporan keuangan pemda yang masih rendah disebabkan oleh permasalahan aset yang masih menjadi salah satu fokus perhatian pemda sejak resmi didirikan dari Kabupaten Simalungun pada 2007 lalu.Yang menjadi persoalannya hingga saat ini, pihaknya sering mendapati sejumlah catatan mengenai aset dari induk Kabupaten simalungun yang masuk ke dalam catatan aset Simalungun pada saat pelimpahan, sementara pada kenyataannya sendiri aset tersebut sudah tidak ada. Misalkan dalam catatan di induk, tapi sebenarnya dari sejak dulu pun aset itu sudah tidak ada di lapangan , Pemda harus kerja keras menata aset-aset yang merupakan pelimpahan dari Kabupaten Simalungun. Aset tersebut mulai dari tanah, bangunan hingga kendaraan.(Maman S Sunjaya 2016).

Rendahnya laporan keuangan, secara umum disebabkan penyusunan laporan keuangan yang belum memenuhi standar akuntansi pemerintah berbasis akrual Dari pemeriksaan BPK, banyak temuan berulang dari tahun ke tahun, tanpa ada keterangan bahwa temuan itu sudah ditindak lanjuti atau belum oleh Pemda. Temuan BPK juga menunjukkan sebagian besar laporan keuangan pemda bermasalah pada pencatatan aset/barang milik daerah, umumnya hal itu terjadi karena pencatatan, keberadaan fisik dan pengungkapannya dalam laporan belum memadai (Beni Ruslandi 2012).

Rendahnya kualitas aparatur pemerintah daerah yang tidak sesuai dengan disiplin ilmu akuntansi yang menyebabkan penyajian laporan keuangan pemerintah daerah Kabupaten simalungun belum optimal karena aparatur belum bisa menyajikan laporan keuangan sesuai dengan standar akuntansi pemerintahan yang baik dan benar .

Berdasarkan latar belakang diatas, maka peneliti tertarik untuk melakukan penelitian dengan judul: "Pengaruh Penerapan Standar Akuntansi Pemerintah dan Kualitas Aparatur Pemerintah Daerah Terhadap Laporan Keuangan Pemerintah Daerah Pada Kantor Camat Pamatang Silima Kuta Kabupaten Simalungun.

\section{TINJAUAN LITERATUR}

\section{Standar Akuntansi Pemerintah}

Berdasarkan Peraturan Pemerintah Republik Indonesia Nomor 71 Tahun 2010 Pasal 1 Ayat (3) tentang Standar Akuntansi Pemerintahan, "Standar Akuntansi Pemerintahan, yang selanjutnya disingkat SAP, adalah prinsip-prinsip akuntansi yang diterapkan dalam menyusun dan menyajikan laporan keuangan Pemerintah.Menurut Sinaga (2005), Standar Akuntansi Pemerintahan merupakan pedoman untuk menyatu kanpersepi antara penyusun, pengguna, dan auditor.Pemerintah pusat dan pemerintah daerah wajib menyajikan laporan keuangan sesuai dengan Standar Akuntansi Pemerintahan (SAP). Pengguna laporan keuangan termasuk legislatif akan menggunakan SAP untuh memahami informasi yang disajikan dalam laporan keuangan dan eksternal auditor (BPK) akan menggunakannya sebagai kriteria dalam pelaksanaan audit. 
Menurut Wijaya (2008: 313) SAP merupakan standar akuntansi pertama di Indonesia yang mengatur mengenai akuntansi pemerintahan Indonesia. Sehingga dengan adanya standar ini, maka laporan keuangan pemerintah yang merupakan hasil dari proses akuntansi diharapkan dapat digunakan sebagai alat komunikasi antara pemerintah dengan stakeholders sehingga tercapai pengelolaan keuangan negara yang transparan dan akuntabel.

Dapat disimpulkan bahwa Standar Akuntansi Pemerintahan adalah suatu konsep dan persyaratan yang mempunyai kekuatan hukum dalam upaya meningkatkan kualitas laporan keuangan pemerintah di Indonesia.Dari beberapa pengertian diatas dapat dinyatakan bahwa Standar Akuntansi Pemerintahan merupakan pedoman wajib dalam menyusun dan menyajikan laporan keuangan dalam pemerintahan, baik pemerintah pusat maupun pemerintah daerah dalam rangka mencapai transparansi dan akuntabilitas.Standar Akuntansi Pemerintahan dapat menjadi pedoman untuk menyatukan persepsi antara penyusun, pengguna, dan auditor.

\section{Pengertian Aparatur Pemerintah Daerah}

Aparatur menurut Kamus Besar Bahasa Indonesia: “Aparatur adalah perangkat, alat (negara, pemerintah); para pegawai (negeri); negara alat kelengkapan negara terutama meliputi bidang kelembagaan, ketata laksanaan dan kepegawaian yang mempunyai tanggung jawab melaksanakan roda pemerintahan sehari-hari; pemerintah pegawai negeri; alat negara; aparatur negara".

Menurut jimmy L.Gaol (2015:133) Aparatur pemerintah adalah aparatur pemerintah baik di pusat maupun di daerah, termasuk BUMN atau BUMD yang berfungsi selaku aparatur perekonomian Negara.

Menurut Undang-Undang Nomor 23 Tahun 2014 tentang Pemerintahan Daerah Perangkat daerah adalah unsur pembantu kepala daerah dan DPRD dalam penyelengaraan Urusan Pemerintah yang menjadi kewenangan Daerah.

SKPD harus memiliki sumber daya yang kompeten, yang di dukung dengan latar belakang pendidikan akuntansi, sering mengikuti pendidikan dan pelatihan, dan mempunyai pengaman di bidang keuangan dalam pengelolaan keuangan daerah yang baik. Hal tebut diperlukan untuk menerapkan sistem akuntansi yang ada. Kegagalan Apaatur Pemerintah Daerah dalam memahami dan menerapan logika akuntansi akan bedampak pada kekeliruan laporan keuangan yang dibuat dan ketidak sesuai yaang ditetapkan pemerintah Warisono (2008).

Berdasarkan uraian diatas dijelaskan bahwa karakteristik sumber daya yang kompeten, yaitu: Pendidikan Formal, Pendidikan atau Pelatihan danPengalaman Kerja.

\section{Pengaruh kualitas Aparatur Pemerintah Daerah Terhadap Laporan Keuangan}

Kualitas merupakan dasar seseorang untuk mencapai kinerja tinggi dalam menyelesaikan kinerjannya. Aparatur pemerintah daerah yang tidak memiliki kualitas tidak akan dapat menyelesaikan pekerjaannya secara efesien, efektif, dan ekonomis. Dalam hal ini pekerjaan yang dihasilkan tidak akan tepat waktu serta tenaga. Dengan adanya kualitas aparatur pemerintah daerah maka waktu pembuatan laporan akan dapat dihemat. Hal ini karena aparatur pemerintah daerah tersebut telah memiliki pengetahuan dan pemahaman mengenai hal-hal yang harus disusun dapat diselesaikan dan disajikan tepat pada waktunya. Semakin cepat laporan keuangan disajikan maka akan semakin baik dalam hal pengambilan keputusan (Mardiasmo, 2002:146).

Dalam menghasilkan suatu nilai informasi yang bernilai (keterandalan) disini menyangkut dua elemen pokok yaitu, informasi yang dihasilkan dan aparatur pemerintah daerah menghasilkannya. Menyangkut informasi laporan keuangan tersebut harus dibuat sedemikian 
rupa sehingga laporan keuangan yang dihasilkan mempunyai kemampuan dalam informasi untuk memberi keyakinan bahwa informasi tersebut benar atau valid. Kemudian menyangkut kemampuan aparatur pemerintah daerah yang akan menjalankan sistem atau yang menghasilkan informasi tersebut, yang dituntut untuk memiliki tingkat keahlian akuntansi yang memadai dan atau paling tidak memiliki keinginan untuk terus belajar dan mengasah kemampuannya di bidang akuntans. Di sini kemampuan aparatur pemerintah daerah itu sendiri sangat berperan dalam menghasilkan informasi yang bernilai (keterandalan) (Wahyono, 2014:12).

\section{METODE PENELITIAN}

Untuk melakukan penelitian ini, data yang diperlukan peneliti adalah data primer.Data primer dalam penelitian ini diperoleh dari kuesioner yang diisi oleh responden.Penelitian ini menggunakanjumlah sampel sebanyak 32 orang, dimana peneliti telah membagikan 35 kuesioner kepada responden di kantor camat pamatang silima kuta Kab. Simalungun.Kuesioner yang kembali hanya 32 buah kuesioner. Sehingga seluruh jumlah kuesioner yang kembali akan dijadikan sampel.

\section{HASIL DAN PEMBAHASAN}

\section{Uji Validitas Dan Realibitas}

Program yang di gunakan untuk melakukan pengujian instrumen yaitu uji validitas dan reabilitas adalah program komputer statistical program for social science (SPSS) Versi 21 yang terdiri dari uji validitas dan reliabilitas, penulis mengimput nilai-nilainya untuk bahan pengujian. Uji validitas yang di gunakan dalam penelitian ini adalah uji validitas butir menurut sugiyono (2003:124). Korelasi angket item dengan skor total $\geq \mathrm{r}$ tabel. Butir pertanyaan tersebut mempunyai korelasi yang signifikan.

Penyebaran kuesioner khusus dalam uji validitas dan realibilitas diberikan kepada 32 responden. Nilai $r$ tabeldengan ketentuan $\mathrm{df}=$ jumlah kasus $=32$ dan tingkat signifikan sebesar $5 \%$ maka angka yang di peroleh $=0.349$.

Tabel 1

\begin{tabular}{cccc}
\multicolumn{4}{c}{ Hasil uji validitas variabel Y, X1, X2 } \\
\hline Pernyataan & $\begin{array}{c}\text { Koefisien } \\
\text { Korelasi }\end{array}$ & r Tabel & Status \\
P1 & 783 & 0.349 & VALID \\
P2 & 676 & 0.349 & VALID \\
P3 & 783 & 0.349 & VALID \\
P4 & 676 & 0.349 & VALID \\
P5 & 479 & 0.349 & VALID \\
P5 & 633 & 0.349 & VALID \\
P7 & 429 & 0.349 & VALID \\
P8 & 755 & 0.349 & VALID \\
P9 & 612 & 0.349 & VALID \\
P10 & 707 & 0.349 & VALID \\
P11 & 720 & 0.349 & VALID \\
P12 & 602 & 0.349 & VALID \\
P13 & 566 & 0.349 & VALID \\
P1 & 622 & 0.349 & VALID \\
P15 & 729 & 0.349 & VALID \\
\hline Sumber:hasil pengolahan SPSS (2020) & & & \\
\hline & & &
\end{tabular}


Tabel1 menunjukkan bahwa seluruh butir pertanyaan kuesioner telah valid karena rhitung >rtabel dengan demikian kuesioner dapat dilanjutkan pada tahap pengujian realibiitas dapat dilihat pada tabel berikut.

Tabel 2

Uji Realibilitas

\begin{tabular}{l}
$\begin{array}{c}\text { Cronbach's } \\
\text { Alpha }\end{array}$ \\
\hline \multicolumn{1}{c}{15} \\
\hline \multicolumn{2}{l}{ Jumber:hasil pengolahan SPSS (2020) }
\end{tabular}

Pada 15 pertanyaan dengan tingkat signifikat 5\% diketahui koefisien alfa (Cronbach's Alpha) adalah sebesar $0.891>0.06$ sehingga dapat di nyatakan bahwa kuesioner tersebut telah reliabel dan dapat di sebarkan kepada responden untuk dijadikan sebagai isntrumen penelitian.

\section{Uji Normalitas}

Uji asumsi klasik di lakukan sebelum melakukan analisis regresi, agar dapat diperkirakan yang tidak bisa dan efensiensi maka dilakukan pengukian asumsi klasik yang harus dipenuhi, yang pertama yaitu uji normalitas. Ada dua cara untuk mendeteksi apakah data berdistribusinormal atau tidak, yaitu dengan pendekatan grafik dan pendekatan kolomogrov smimov.

\section{Uji Multikonolinieritas}

Uji multikonolinieritas bertujuan untuk menguji apakah pada model regresi ditemukan adanya korelasi antara variabel independen. Jika VIF lebih besar berada dibawah 10.00 dan nilai tolerance lebih dari 0.100 , maka tidak terdapatmasalah pada multikonolinieritas.terjadi korelasi, maka masalah multikonolinieritas. Pada model regresi yang baik tidak terjadi korelasi di antara variabel independen hasil pengujian multikonolinieritas data dalam penelitian ini menggunakan alat bantu SPSS, hasilnya dapat dilihat pada tabel 3 berikut.

Tabel 3

Uji Multikonolinieritas

\begin{tabular}{lllcr}
\hline & & Model & \multicolumn{2}{c}{ Collinearity Statistics } \\
\cline { 3 - 4 } & & & Tolerance & VIF \\
\hline \multirow{2}{*}{1} & (Constant) & \multicolumn{3}{c}{} \\
& TOTAL_X1 & .590 & 1.694 \\
& TOTAL_X2 & .590 & 1.694 \\
\hline
\end{tabular}

a. Dependent Variable: TOTAL_Y

Sumber:hasil pengolahan SPSS (2020)

Dari hasil tabel tabel 3 dapat diketahui nilai variance inflation factor (VIF) kedua variabel yaitu penerapan standar akuntansi pemerintah (X1) dan kualitas aparatur pemerintah daerah (X2) adalah 1.6941 lebih kecil dari 10 dan tolerance lebih dari 0.100 sehingga dapat disimpulkan bahwa antar variabel independen tidak terjadi persoalan multikonolinieritas.

\section{Uji Heteroskedasitas}

Heteroskedaritas diduga untuk mengetahui adanya atau tidaknya penyimpangan asumsi klasik heteroskedaritas adanya ketidak samamaan varian dari rasidual untuk semua pengamatan pada model regresi. 


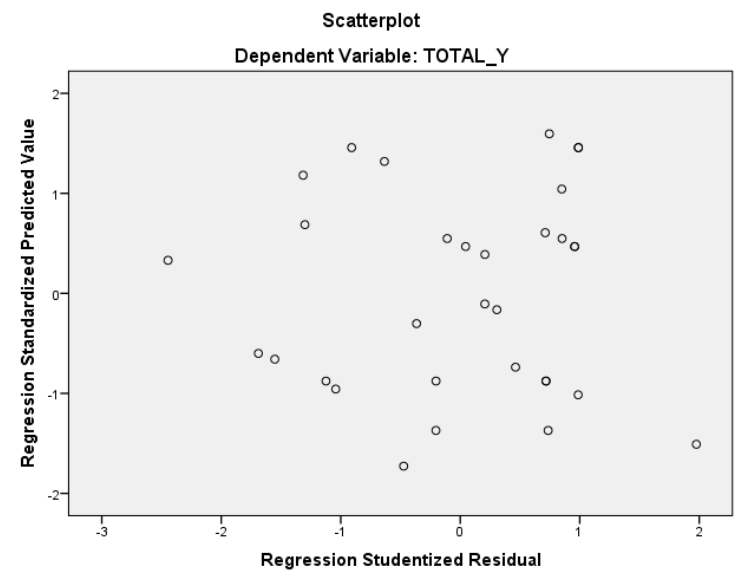

Gambar 1. Uji Heteroskedasitas

Sumber:hasil pengolahan SPSS (2020)

Berdasarkan gambar dapat dilihat dari grafik scatterplot yang disajikan terlihat titik -titik menyebar secara acak tidak membentuk suatu pola tertentu yang jelas serta tersebar baik diatas maupun dibawah angka 0 pada sumbu Y. Hal ini berarti tidak terjadi heteroskedasitas pada model regresi,sehingga model regresi layak di pakai untuk memprediksi laporan keuangan pemerintah daerah berdasarkan masukan variabel independennya.

\section{Uji Regresi Linear Berganda}

\begin{tabular}{|c|c|c|c|c|c|c|}
\hline \multirow{2}{*}{\multicolumn{2}{|c|}{ Model }} & \multicolumn{2}{|c|}{ Unstandardized Coefficients } & \multirow{2}{*}{$\begin{array}{l}\text { Standardized } \\
\text { Coefficients }\end{array}$} & \multirow[t]{2}{*}{$\mathrm{T}$} & \multirow[t]{2}{*}{ Sig. } \\
\hline & & B & Std. Error & & & \\
\hline \multirow{3}{*}{1} & (Constant) & -.128 & 2.334 & & -.055 & .956 \\
\hline & TOTAL_X1 & .723 & .114 & .719 & 6.329 & .000 \\
\hline & TOTAL_X2 & .280 & 139 & .228 & 2.011 & .054 \\
\hline
\end{tabular}

a. Dependent Variable: TOTAL_Y

Sumber:hasil pengolahan SPSS (2020)

Berdasarkan hasil pengujian statistik pada regresi linear berganda di atas, maka melalui persamaan regresi di bawah ini di jabarkan sebagai berikut.

$Y=a+b 1 x e+e$

$\mathrm{Y}=-0.128+0.723 \mathrm{X} 1+0.280 \mathrm{X} 2$

Berdasarkan persamaan tersebut dapat dijelaskan sebagai berikut:

a. Konstanta $=-0.128$

Berdasarkan analisis regresi linear berganda di atas dapat di lihat bahwa penerapan standar akuntansi pemerintah (X1) dan variabel kualitas aparatur pemerintah daerah (X2) dianggap konstan atau tetap, maka variabel laporan keuangan pemerintah daerah sebesar -0.128. Dari persamaan regresi diatas terlihat bahwa nilai konstanta sebesar yang artinya jika tidak ada 
penerapan standar akuntansi pemerintah (X1) dan variabel kualitas aparatur pemerintah daerah (X2) maka laporan keuangan pemerintah daerah (Y) tetap sebesar -0.128

b.Koefisien X1b1 = 0.723

Ini menunjukan bahwa hubungan antara variabel penerapan standar akuntansi pemerintah (X1) dalam meningkatkan laporan keuangan pemerintah daerah (Y) sebesar 0.723.Hal ini menunjukkan bahwa apabila penerapan standar akuntansi pemerintah (X1) ditingkatkan sebesar 1 satuan, maka laporan keuangan pemerintah daerah akan meningkat sebesar 0.723 .

\section{c.Koefisien $\mathrm{X} 2 \mathrm{~b} 2=0.280$}

Ini menunjukkan bahwa hubungan antara variabel kualitas aparatur pemerintah daerah meningkatkan laporan keuangan pemerintah daerah sebesar 0.280. Hal ini menunjukkan bahwa apabila kualitas aparatur pemerintah daerah ditingkatkan 1 satuan, maka laporan keuangan pemerintah daerah akan meningkat sebesar 0.280.

\section{Pengujian Hipotesis Simultan}

Pengujian yang dilakukan secara simultan dapat diperoleh pembuktian hipotesis dalam penelitian ini adalah penerapan standar akuntansi pemerintah (X1) kualitas aparatur pemerintah daerah (X2) secara bersama - sama berpengaruh terhadap laporan keuangan pemeintah daerah (Y). Ketentuan data yang diperlukan untuk menguji hipotesis di atas adalah sebagai berikut.

Tabel 6

$\mathrm{Uji}_{\mathrm{F}}$ ANOVA ${ }^{\mathrm{a}}$

\begin{tabular}{|c|c|c|c|c|c|c|}
\hline Model & & $\begin{array}{l}\text { Sum of } \mathrm{Df} \\
\text { Squares }\end{array}$ & & $\begin{array}{l}\text { Mean } \\
\text { Square }\end{array}$ & $\mathrm{F}$ & Sig. \\
\hline \multirow[t]{3}{*}{1} & Regression & 127.773 & 2 & 63.887 & 51.142 & $.000^{\mathrm{b}}$ \\
\hline & Residual & 36.227 & 29 & 1.249 & & \\
\hline & Total & 164.000 & 31 & & & \\
\hline
\end{tabular}

a. Dependent Variable: TOTAL_Y

b. Predictors: (Constant), TOTAL_X2, TOTAL_X1

Sumber:hasil pengolahan SPSS (2020)

Berdasarkan tabel 4.28 dapat dilihat dari perolehan Fhitung pada kolom F yakni sebesar 51.142 dengan tingkat signifikan $=0.000$ sedangkan Ftabel sebesar 3. 42, menunjukkan bahwa H0 ditolak dan Ha diterima karena Fhitung > Ftabel.Berarti penerapan standar akuntansi pemerintah (X1) dan kualitas aparatur pemerintah daerah (X2) secara serempak berpengaruh secara posituf dan signifikan terhadap variabel laporan keuangan daerah (Y).

Tabel 7

Koefisien Korelasi dan R-Square Model Summary ${ }^{\mathrm{b}}$

\begin{tabular}{|l|c|r|r|r|}
\hline Model & $\mathrm{R}$ & $\begin{array}{c}\mathrm{R} \\
\text { Square }\end{array}$ & $\begin{array}{c}\text { Adjusted } \\
\text { R Square }\end{array}$ & $\begin{array}{r}\text { Std. Error of } \\
\text { the Estimate }\end{array}$ \\
\hline 1 & \multicolumn{1}{|c}{$.883^{\mathrm{a}}$} & .779 & .764 & 1.118 \\
\hline
\end{tabular}

a. Predictors: (Constant), TOTAL_X2, TOTAL_X1

b. Dependent Variable: TOTAL_Y

Sumber:hasil pengolahan SPSS (2020) 
Berdasarkan hasil perhitungan SPSS diperoleh berdasarkan perhitungan koefisien determinasi, dapat dilihat nilai Asjusted R Square yang diperoleh sebesar 0.419. Untuk melihat besar pengaruh variabel bebas terhadap veriabel terikat dengan cara menghitung koefisien determinasi $(\mathrm{KD})=\mathrm{R} 2 \times 100 \%$, sehingga diperoleh $\mathrm{KD}=76.4 \%$. Angka tersebut menunjukkan bahwa sebesar $76.4 \%$ leporan keuangan pemerintah daerah (variabel terikat) dapat dijelaskan penerapan standar akuntansi pemerintah dan kualitas aparatur pemerintah daerah. Sisanya sebesar $23.6 \%$ dipengaruhi oleh faktor -faktor lain yang tidak dijelaskan daam penelitian ini.

\section{KESIMPULAN}

Dari hasil pemaparan dan pembahasan data di atas maka kesimpulan dari hasil penelitian adalah:

1. Secara simultan, penerapan standar akuntansi pemerintah dan kualitas aparatur pemerintah daerah berpengaruh secara positif dan signifikan terhadap laporan keuangan pemerintah daerah pada kantor camat pamatang silima kuta Kab. Simalungun.

2. Secara parsial, hanya standar akuntansi pemerintah yang berpengaruh secara positif dan signifikan terhadap laporan keuangan pemerintah daerah pada Kantor camat pamatang silima kuta Kab. Simalungin.

3. Kualitas aparatur pemerintah daerah berpengaruh positif nsmun tidak signifikan terhadap laporan keuangan pemerintah daerah pada kantor camat pamatang silima kuta Kab. Simalungun.

4. Berdasarkan nilai R Square diperoleh angka sebesar 0.465 yang berarti bahwa $46.5 \%$ laporan keuangan di pengaruhi oleh standar akuntansi pemerintah dan kualitas aparatur pemerintah, sedangkan 53.5\% sisanya dipengaruhi oleh variabel lain yang tidak diteliti pada penelitian ini.

Berdasarkan kesimpulan yang diambil, maka saran yang dapat diberikan adalah:

1. pemerintahan kantor camat sebaiknya memperbaiki dan meningkatkan aspek - aspek mengenai penyajian laporan keuangan daerah, seperti penyajian laporan yang lengkap, tepat waktu, mudah dipahami,dan lain sebagainya guna meningkatkan kepercayaan masyarakat yang berwujud terhadap peningkatan kualitas aparatur,pengelolaan keuangan.

2. Pemerintahan kantor camat lebih meningkatkan dan mengikuti peraturan SAP pemerintah unruk mendaatkan laporan keungan yang baik.

3. Pemerintahan kantor camat lebih meningkatkan kualitas aparatur pemerintah supaya dapat laporan keungan yang baik.

4. Diharapkan kepada peneliti selanjutnya agar dapat lebih menyempurnakan penelitian ini dengan menggunakan variabel - veriabel lain yang lebih lengkap dan beragam.

\section{DAFTAR PUSTAKA}

Bastian, Indra, 2010. Akuntansi Sektor Publik Suatu Pengantar, Yogyakarta: Erlangga,

Halim, Abdul dan Muhammad Syam Kusufi. 2013. Akuntansi Sektor Publik Akuntansi Keuangan Daerah,Jakarta: Salemba Empat.

Hoesada, Jan. Bunga Rampai. 2016. Akuntansi Pemerintahan, Jakarta: Salemba Empat.

Juwita, Rukmi. 2013. Pengaruh Implementasi Standar Akuntansi Pemerintah dan Sistem Informasi Akuntansi Terhadap Kualitas Laporan Keuangan, dalam jurnal Trikonomika, Volume 12, No 2: 1411-514X, 
Laporan Keuangan Pemerintah Kabupaten Labuhanbatu tahun 2015

Ningtyas, Pravitasari Eka. Pengaruh Efektivitas Penerapan Standar Akuntansi Pemerintahan Terhadap Kualitas Laporan Keuangan Pemerintah Daerah, dalam Jurnal Ilmu dan Akuntansi, Vol. 4 Nomor 1.

Moleong, Lexy. 2014. Metode Penelitian Kuaitatif,Bandung: Remaja Rosdakarya.

Nordirawan, Deddi, et. al., 2009. Akuntansi Pemerintah, Jakarta: Salemba Empat,

Nurlaila, 2014. Pengaruh Efektivitas Penerapan Standar Akuntansi Pemerintah Terhadap Kualitas Laporan Keuangan Pemerintah Daerah Kabupaten Enrekang, Skripsi, Universitas Hasanuddin Makasar,

Prasetya, Gede Edy,Andi 2013. Penyusunan \& Analisis Laporan Keuangan Pemerintah Daerah, Yogyakarta.

Peraturan Menteri Dalam Negeri Nomor 64 Tahun 2013 tentang Penerapan Standar Akuntansi Pemerintah.

Peraturan Pemerintah Republik Indonesia Nomor 71 Tahun 2010 tentang Standar Akuntansi Pemerintah.

QS. Al-Baqarah ayat 282.

Renyowijoyo, Muindro, 2013. Akuntansi Sektor Publik Organisasi Nir Laba, (Jakarta: Mitra Wacana Media,.

Ritonga, Andika Fransiska, 2015. Pengaruh Penerapan Standar Akuntansi Pemerintahan dan Kompetensi Sumber Daya Manusia Terhadap Kualitas Laporan Keuangan Pemerintah Daerah pada DPKAD Pemerintahan Kota BandungSkripsi, Fakultas Ekonomi Universitas Widyatama Bandung.

Saroso, Samiaji, 2012. Penelitian Kualitatif: Dasar-dasarJakarta: Indeks Penerbit.

Sumarsono, Soony, 2010. Manajemen Keuangan Pemerintahan, Yogyakarta: Graha Ilmu.

Sugiono, 2010. Metode Penelitian Kuantitatif Kualitatif dan R\&D, Bandung: Alfabeta.

Udiyanti, Ni Luh Nyoman Ari, 2014. Pengaruh Penerapan Standar Akuntansi Pemerintahan, Sistem Pengendalian Internal, dan Kompetensi Staf Akuntansi Terhadap Kualitas Laporan Keuangan Pemerintah Daerah Studi kasus pada SKPD Kabupaten Buleleng dalam jurna S1 Ak Universitas pendidikan Ganesha, Volume 2 No: 1

Utami S, Intan Safrina, 2012. Pengaruh Penerapan Sistem Akuntansi Instansi Terhadap Pengelola Keuangan pada Satuan Kerja Perencanaan dan Pengendalian Program Infrastruktur Pemukiman Sumatera Utara, Skripsi Akuntansi Universitas Negeri Medan 